\title{
25 Research Soure \\ Relevance of Connexin 26 (GJB2) Gene Mutations With Congenital Nonsyndromic Sensorineural Hearing Loss in Lraqi Deafness Patients.
}

Anwar Madlool Al-janabi ( $\sim$ anwar.aljanabi@uokufa.edu.iq )

Kufa University School of Medicine: University of Kufa College of Medicine https://orcid.org/0000-0002-18189062

\section{Habeeb Shuhaib Ahmmed}

Kufa University School of Medicine: University of Kufa College of Medicine

Salih Mahdi Alkhafaji

Kufa University School of Medicine: University of Kufa College of Medicine

\section{Primary research}

Keywords: GJB2, connexin 26, mutations, PCR-RFLP, Iraq

Posted Date: January 15th, 2021

DOI: https://doi.org/10.21203/rs.3.rs-139090/v1

License: (c) (i) This work is licensed under a Creative Commons Attribution 4.0 International License. Read Full License 


\section{Abstract}

Objective: This study aimed to detect the frequency of the three most common mutations of GJB2 in nonsyndromic sensorineural deafness for Iraqi population.

Method: The current case-control study was conducted from January 2018 to November 2019 at ENT Departments from middle Euphrates region of Iraq. The study was included 95 deaf patients group (55 males and 40 females) their age range between 11-40 years old and $21.5 \pm 6.3$ year (mean \pm SD). and 110 healthy control group, their ages range between 10-40 years old and $20.1 \pm 5.9$ year (mean \pm SD), these two groups were matched in age and gender. In order to detect c.35delG, 235delC and 167delT mutations in GJB2 gene, we were employed the polymerase chain reaction - restriction fragment length polymorphism (PCR-RFLP) technique.

Results: From 95 deaf patients with non syndromic hearing loss (NSHL), were participated in this study. The c.35delG was the main frequent mutation encountered with GJB2 gene, of the 95 patients, 38(40\%) were heterozygous and the others $57(60 \%)$ were homozygous genotypes. The second degree mutation in GJB2 gene was c.235delC mutation. Which from the 95 deaf patients, 35 (36.8\%) were carried out homozygous, 5 (5.3\%) were carried out heterozygous and 55(57.9) of the study individuals were appeared wild genotypes. None of the 95 deaf patients were showed the c.167delT mutation, while Connexin 26 studied mutations were not detected in healthy control group.

Conclusion: Our data conclude that the GJB2 c.35delG and c.235delC gene mutations were the main cause of congenital hearing loss in Iraqi deaf population.

\section{Introduction}

Deafness is the complete or partial loss of hearing ability, which affects 6 - $8 \%$ in the populations of developing countries in any ages and with different levels of severity. It is consequent to societies and individuals, which are highly affected by the age of manifestation and its severity. When it appears early in childhood and comprises severe defect, it causes significant profound limitations of speech aquizition and following by psychosocial defects. While in elderly, it affects the life features by the social isolation of an individual ${ }^{(1)}$.

Congenital Hearing loss is the most common form of sensory defect in human beings, with about 1/1000 infants born with a severe hearing deficit ${ }^{(2)}$. Inherited hearing loss was divided into two types: the 1 st type is syndromic and the 2 nd type is non syndromic. The syndromic type, which accounts $30 \%$ of inherited congenital deafness, is associated with other clinical characteristics . The non-syndromic type, which represents the other $70 \%$, is only clinical appearance of deafness ${ }^{(3)}$. Regarding to the non-syndromic hearing loss (NSHL), autosomal recessive is the major common form that accounting $75 \%$ to $85 \%$ of deaf cases $^{(4,5)}$.

More than 100 genes may be implicated in NSHL, but the higher risk of mutations were found in the protein of gap junction, connexin 26 (GJB2). Which is one of a large family of proteins that forms gap junction in close to every cell type. This junction is consisted of multimeric connexons, that allows the molecules to pass from cell to another cell. The connexons are contained of connexins, which are differ in cell specificity and their properties of gating $^{(6)}$.

The gene that encodes the gap junction protein GJB2 was located on chromosome 13q11-12 and was reported to have up to $50 \%$ mutations in all patients from various populations. In spite of numerous mutations were 
recognized (35delG, 235delC, 167delT, V37I, 109G-A, etc), but 235delC was found to be the most common GJB2 mutation in East Asians populations, c.35delG in Caucasians and 167delT predominant in Ashkenazi Jews (7-10).

There is no molecular study of GJB2 gene was recorded in Iraqi population with non syndromic sensorineural hearing loss. for that reason, this study was aimed to investigate the common c.35delG, c.235delC and c.167delT mutations in the gene of connexin 26 (GJB2) in Iraqi deaf patients.

\section{Patients And Methods}

The current case-control study was conducted from January 2018 to November 2019 at ENT Departments from middle Euphrates region of Iraq. The study was included the consent forms approved by medical ethics committee in Faculty of Medicine, Kufa University, Iraq. The sample size was calculated by using the online software OSSE (online sample size estimator) ${ }^{(11)}$. Ninety five patients were diagnosed with bilateral nonsyndromic sensorineural hearing loss (NSHL), they were ( 55 males and 40 females) their ages between 11-40 years old and $21.5 \pm 6.3$ year (mean \pm SD). Among them, 75 were sporadic cases of hearing loss, compatible with recessive inheritance while the other 20 probands were from families with more than one sib of non-syndromic hearing loss, age and gender were matched with control group which were consisted of 110 voluntary individuals unrelated to patients, they were selected from general population and apparently healthy, their ages ranged between $10-40$ years old and $20.1 \pm 5.9$ year (mean \pm SD). Only individuals free from signs and symptoms of any chronic diseases such as DM, cardiac diseases, hypertension, renal diseases or others were selected to participate in this study.

Consent information was obtained from all participants relatives and patients younger than 18 years from their parents. Assessment was included a complete case history, using Pure Tone Audiometry and physical examination, the inclusion criteria was the ultimately finding of examinations with NSHL. While the exclusion criteria was acquired hearing loss related to environmental causes and patients who diagnosed with syndromic hearing loss were excluded from current study.

\section{Audiology}

All study participants underwent pure-tone audiometry by using diagnostic audiometer instrument (Siemens Danplex DA 74 clinical diagnostic audiometer, USA) in a soundproof room. Which averages pure-tone of more than $25 \mathrm{dBHL}$ ( $\mathrm{dBHL}$ at 500, 1000, and $2000 \mathrm{~Hz}$ ) were definite as hearing loss according to the hearing loss classification ${ }^{(12)}$.

\begin{tabular}{|ll|}
\hline Degree of Hearing Loss Tone Average & Hearing Loss range(dB HL). \\
\hline Normal & -10 to 15 \\
\hline Slight & 16 to 25 \\
\hline Mild & 26 to 40 \\
\hline Moderate & 41 to 55 \\
\hline Moderately severe & 56 to 70 \\
\hline Severe & 71 to 90 \\
\hline Profound & 91 to equipment limits \\
\end{tabular}


The hearing impairment degrees were ranged from moderate to profound in current study.

\section{Mutation Analysis}

One $\mathrm{ml}$ of venous blood was collected from all individuals participated in this study. Genomic DNA was isolated and purified from peripheral blood lymphocytes by using ReliaPrep ${ }^{\text {TM }}$ Blood gDNA Miniprexp System (Promega) according to the standard protocol of the manufacturer.

The DNA was extracted then used in the screening of selected mutations. Polymerase Chain Reaction-Restriction fragment length polymorphism (PCR-RFLP) analyses were applied to detect the three GJB2 common mutations that described previously and as appeared in Table 1. Restriction enzymes and PCR primers were purchased from Biolabs (USA). The amplification of GJB2 genes were performed by using genomic DNAs (100-200 ng) in $25 \mu \mathrm{l}$ master mix containing 50mM KCl, $1.5 \mathrm{mM} \mathrm{MgCl} 2,10 \mathrm{mM}$ Tris $\mathrm{HCl}(\mathrm{pH} 8,3), 200 \mathrm{M}$ dNTPs and $1.25 \mathrm{U}$ tag DNA Polymerase (Promega, USA) and $10 \mathrm{pmol}$ of each primer. The PCR procedure was done by incubation at $94^{\circ} \mathrm{C}$ for $15 \mathrm{sec}$. followed by $35 \mathrm{cycles}$ of $94^{\circ} \mathrm{C}$ for $30 \mathrm{sec}, 55^{\circ} \mathrm{C}$ for $30 \mathrm{sec}$. and $72{ }^{\circ} \mathrm{C}$ for $60 \mathrm{sec}$. Then the products of PCR were digested by using Bstl, Apal and Mwol enzymes to search of the connexin 26 (GJB2) variations c.35delG, c.235delC and c.167delT respectively.

Wild type PCR products were cut by the enzymes in c.35delG and c.235delC genes and showed two bands in gel electrophoresis, whereas 167delT mutated gene was uncut and produced single band when applied by electrophoresis in $2 \%$ agarose gel stained with ethidium bromide, and the results were recognized by gel documentation instrument.

\section{Results}

The study was involved three mutations in connexin 26 (GJB2) gene related with non syndromic autosomal recessive deafmute in 95 patients. Among them, 55 (57.9\%) were males and 40 (42.1\%) were females. The results of questionnaire were appeared that endogamy marriage between parents of deaf patients is more common which accounts (80\%), and there is a family history in the mother's family (39\%) or the father's family (42\%). As well as, $89 / 95$ (94\%) of the patients' parents have normal hearing. The presented data for five of remaining sex patients was appeared that their paternal and maternal grandparents have normal hearing. hence, from the interview outcomes were considered all patients as having autosomal recessive non syndromic hearing loss.

A total of 95 deaf patients with NSHL who recruited in this study, were included 75 simplex proband which refers to sporadic patients whose families have no one suffering from hearing loss and 20 multiplex proband which means that there is at least one first or second degree deaf relative in their families. Clinical characteristics of deaf patients were summarized in Table 2. Hearing tests confirmed that the level of hearing loss was severe to profound in 91 patients. The remaining 4 patients showed moderate hearing loss as appeared in Table 2.

The c.35delG was recorded as the mainly frequent encountered mutation in GJB2 gene, all ninety five patients were appeared clearly mutation in this gene either heterozygous genotype (one allele mutant copy) or homozygous genotype (two allele mutant copies). Of the ninety five deafness sensorineural patients, thirty eight (40\%) were found to have heterozygous genotype while the other fifty seven (60\%) were appeared homozygous genotype of the tested mutation as in figure (1). 
On the other hand, c235delC mutation was represented as the second degree mutation in GJB2 gene. Where from the ninety five deaf patients, thirty five (36.8\%) were carried out homozygous genotype (two allele mutant copies) and five (5.3\%) were carried out heterozygous genotype (one allele mutant copy). However, 55(57.9) of the study individuals were showed wild genotype for the tested mutation as in figure (2).

None of the 95 deaf patients showed the c.167delT mutation. As well as there were no mutations appeared in control group. The frequency of the detected mutations is summarized in Table 3.

\section{Discussion}

The GJB2 gene which encodes connexins 26, these proteins are dependent in both terms of expression and localization. Within the cochlea, connexins 26 form heterometric gap junctions which obviously contribute to the up keeping homeostasis of cochlea. The mutation of this gene as heterozygous or homozygous form influenced on the actions of the gap junctions and therefore prevent the conversion of the mechanical signal to the electrical signal. Hence deafness was installed as symmetrical and bilateral, most often severe or profound ${ }^{(13)}$.

This study was investigated three GJB2 mutations in NSHL from middle Euphrates region of Iraq. The distribution of connexin 26 (GJB2) mutations widely differs among ethnicities. The results were revealed that the c. 35delG was evident in $65(68.4 \%)$ which was agreed with (70\%) prevalence of the c.35delG mutation recorded in Cuba and (74\%) in Spain for studying patients by Yenitse et al from Cuba and Spain ${ }^{(14)}$. As well as, The GJB2 c.35delG mutation was recorded in (60\%) of North European and Turkish who suffer from hereditary deafness ${ }^{(15,16)}$. It was arranged among the highest mutation in GJB2 when compared with its frequency in other Arabic populations rates. The GJB2 mutations account in Algeria 40\%, in Lebanon 33.3\%, in Palestine 23\%, in Tunisia 17\% and in Jordanian $16.9 \%$. However, this mutation very rare in Asian patients and it is frequently encountered GJB2 mutation in Caucasians ${ }^{(17)}$.

Another less frequent frameshift mutation, c.235delC was reported in this study. Which detected in $40(42.1 \%)$ from all NSHL patients including 35 (36.8\%) homozygous and 5 (5.3\%) Heterozygous genotypes of mutant alleles. The c.235delC mutation was found as the most common mutation cause premature protein termination in patients suffering from hearing loss in East and Southeast Asia, while lower frequencies was recorded in Oceania and Europe ${ }^{(18-20)}$. It was also presented in Japanese, Korean, and Mongolian populations ${ }^{(8,21-23)}$. for that reason, mutation in GJB2 was a significantly contributed to the recessive inheritance NSHL in the Chinese population, as also appeared in another ethnic group ${ }^{(24)}$.

The third mutation c.167delT in GJB2 gene, which was not appeared in our study subjects, was mainly presented in Ashkenazi Jews ${ }^{(7)}$. Also, this mutation was detected in a Palestinians group from Bethlehem ${ }^{(2)}$, which representing that the variant of GJB2 mutant allele frequency also may be marked in the groups of the similar population.

Number of studies demonstrate a shared sources of the mutation in GJB2, such as the R143W mutation in a numerous families in a Ghanaian village and the 167 delT mutation in Ashkenazi Jews $(7,25)$.

The variation between various studies in type of GJB2 mutations and terms of frequency associated with NSHL may be due to several causes that include: sample size (large sample size increase the probability for detecting 
rare mutations), selection criteria of the patients investigated, accuracy of genotyping method that employed and consanguineous marriage rate.

\section{Conclusion}

Connexin 26 (GJB2) , c.35delG and c.235delC gene mutations was a causative agent for congenital hearing loss in Iraqi population. These data can support the screening programs of audiometric recognizing neonates with congenital inherited hearing loss in Iraqi endogamy parents.

\section{Abbreviations}

A Adenine

Bp Base pair

Mwol Methanothermobacter wolfeii

Apal Acetobacter pasteurinus

BstUI Bacillus stearothermophilus

C Cytosine

C.I Confidence interval

DM Diabetes mellitus

DNA Deoxy ribose nucleic acid

dNTPs Deoxy ribose nucleotide triphosphate

M Moler

mM Milli Moler

GJB2 gap junction B2

NSHL non-syndromic hearing loss

$\mathrm{MgCl} 2$ Magnesium chloride

MI Milliliter

SD Standard deviation

Del Deletion

Pg Pictogram

G Guanine 
T Thymine

No. Number

A Adinine

OR Odds ratio

OSSE Online sample size estimator

Q long arm of chromosome

P Probability

$\mathrm{KCl}$ Potassium chloride

U Unit

PCR Poly chain reaction

RFLP Restriction fragment length polymorphism

Rs Reference SNP

F Forward

R Reverse

Declarations

Ethics approval 

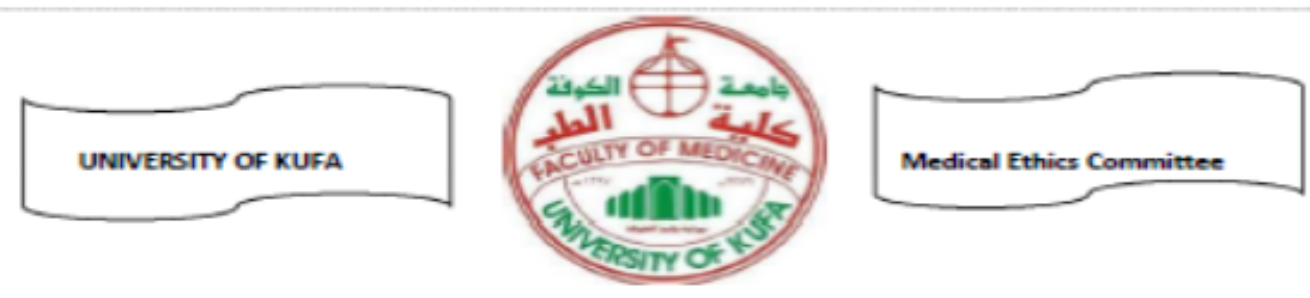

FINAL APPROVAL LETTER

Date : May 21,2018

Title of Project: Relevance of Connexin 26 (GIB2) gene mutations with congenital nonsyndromic sensorineural hearing loss in Iraqi deafness patients.

Referencelt: MEC-21

Principal Author: Dr. Anwar Al-janabi, Department of Biochemistry. College of Mkdicine University of Kufa, Iraq.

Co-Authors:

Dr. Habeeb Shuhaib Ahmmed, Department of Otolaryngolog, Colk ge of Medicine, Univensity of Kufa, Najat, lraq.

Dr. Salih Al-Khafaji, Department of Anatomy \& Histology, College of Medicine, University of Kufa, Iraq-

Dear Dr. Anwar Al-janabi:

Thank you for your recent correspondence. Approval for the above application has been sranted, effective May 21,2018 . You may now proceed with your research.

NRHadi

Dr. Najah R Hadi

Professor and Consultant

Head of the Ethical committee for the clinical studies

Faculty of Medicine

University of Kufs

Cell 009647801241456

E-mail: naiph alzamilipuokufo.edu.iq 
SPRINGER NATU Springer

Consent form for Publication

I am Dr. Anwar Al-janabi, I promise to give my consent for information about myself to be published in [Human Genomics journal]

Manuscript number: HUGM-D-20-00126]

Corresponding author: Dr. Anwar Madlool Al-janabi

NB: In cases where the patient has died or is incapable of giving consent, consent may be given by the next of kin. if the patient is under the age of 16 , consent should be given by a parent or guardian.

I understand that the text and any pictures published in the article

1. will be used only in educational publications intended for professionals Or

2. if the publication or product is published on an open access basis, I understand that it will be freely available on the internet and may be seen by the general public.

The pictures and text may also appear on other websites or in print, may be translated into other languages.

I understand that the information will be published without my name attached, but that full anonymity cannot be guaranteed.

I have been offered the opportunity to read the manuscript.

1 acknowledge that it is not possible to ensure complete anonymity, and someone may be able to recognize me. However, by signing this consent form I do not in any way give up, waive or remove my rights to privacy. I may revoke my consent at any time before publication, but once the information has been committed to publication ("gone to press"), revocation of the consent is no longer possible.

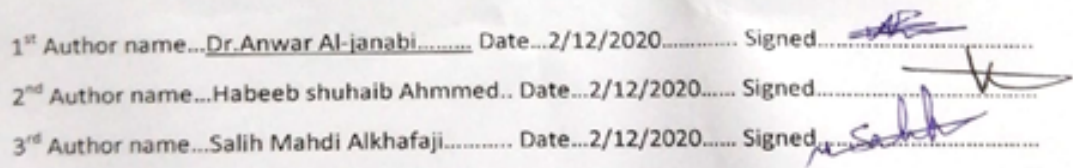

Please keep this consent form in the patient's case files. The manuscript reporting this patient's details should state that 'Written informed consent for publication of their clinical details and/or clinical images was obtained from the patient/parent/guardian/ relative of the patient. A copy of the consent form is available for review by the Editor of this journal.

\section{Competing Interest}

The authors declare that they have no competing interests.

Funding: No funding support 


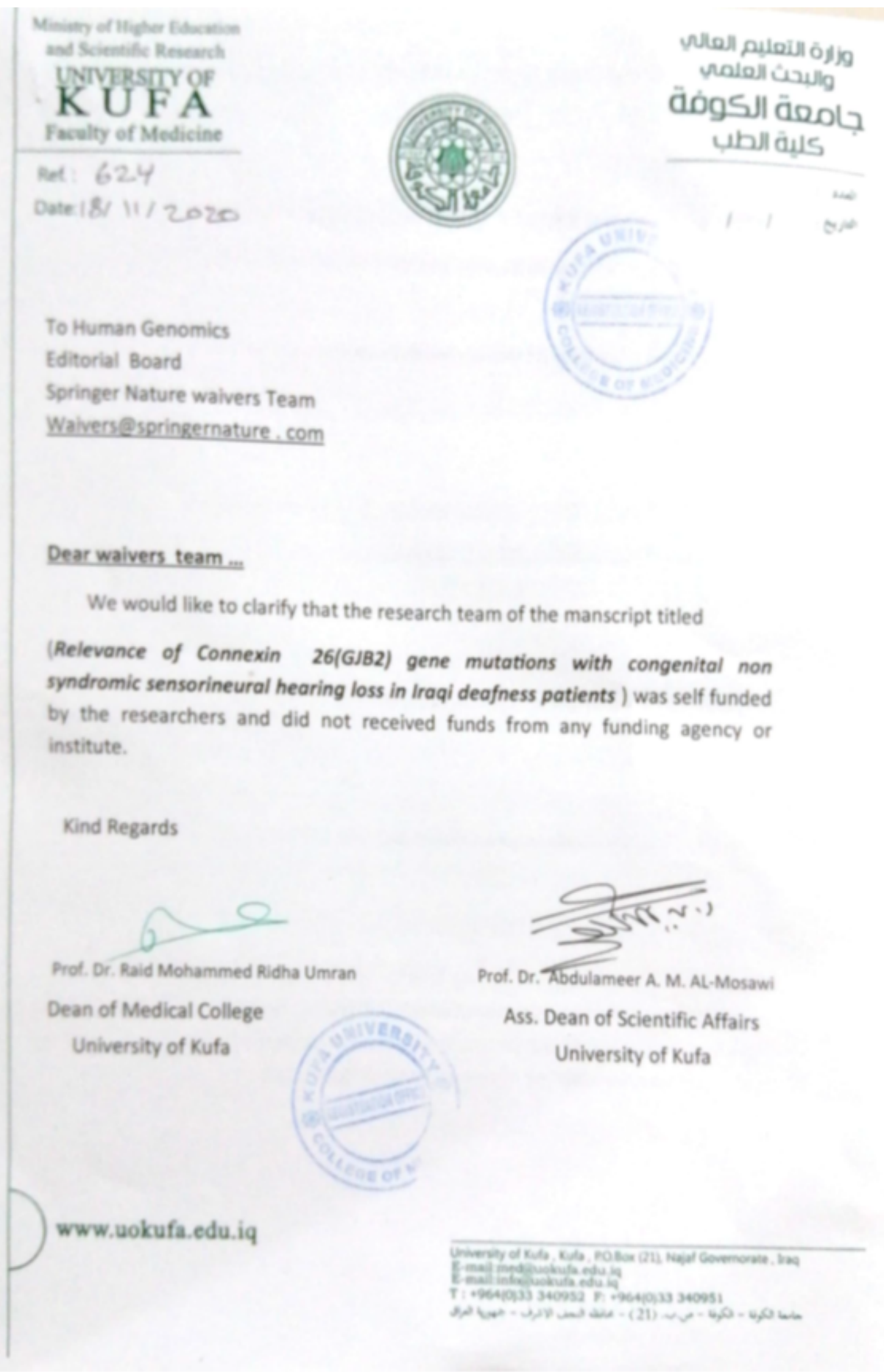

\section{Authors contributions}

Informations and sample collection were done by Dr. Anwar, Dr. Salih and Dr. Habeeb

Audiology of hearing was done by Dr. Habeeb

Genetic analysis was done by Dr. Anwar and Dr. Salih

Statistical analysis was calculated by Dr. Anwar

Manuscript was written by Dr. Anwar and Dr. Salih 
Revision of the manuscript by Dr. Anwar, Dr. Salih and Dr. Habeeb

\section{Acknowledgements}

The authors want to thank the staff of the ENT Departments from Middle Euphrates region of Iraq for their supporting during sample collection, mainly ENT Department in Al-Sadder hospital in Najaf/ Iraq.

\section{References}

1. Petit C, Levilliers J, Marlin S, Hardelin J. Multisystem inborn errors of development: Hereditary Hearing Loss. $2011 ; 254:$ 6281-328.

2. Shahin H, Walsh T, Sobe T, Lynch E, Claire KM, Avraham KB, et al. Genetics of congenital deafness in the Palestinian population: multiple connexin 26 alleles with shared origins in the Middle East. Hum Genet. 2002; 110:284-289.

3. Matsunaga T. Value of genetic testing in the ontological approach for sensorineural hearing loss. Keio $\mathrm{J}$ Med. 2009; 58: 216-222.

4. Snoeckx RL, Hassan DM, Kamal NM, Den Bogaert KV, Camp GV. Mutation Analysis of the GJB2 (Connexin 26) Gene in Egypt. Human Mutation 2005; 26 : 60-61.

5. Ibrahim SM, Ali M, Ahmad S, Ali L, Muhammad N, Tareen R, et al. Autosomal Recessive Deafness is Heterogeneous in Pakistani Pakhtun Population. Curr. Res. J. Biol. Sci. 2011; 3 : 17-24.

6. Boase NA and Kumar S. NEDD4: the founding member of a family of ubiquitin-protein ligases. Gene 2015; 557:113-122

7. Morell RJ, Kim HJ, Hood LJ, Goforth L, Friderici K, Fisher R, et al. Mutations in the connexin 26 gene (GJB2) among Ashkenazi Jews with nonsyndromic recessive deafness. N Engl J Med. 1998; 339:1500-1505.

8. Kudo T, Ikeda K, Kure S, Matsubara Y, Oshima T, Watanabe K, et al. Novel mutations in the connexin 26 gene (GJB2) responsible for childhood deafness in the Japanese population. Am J Med Genet. 2000; 90: 141-145

9. Kudo T, Ikeda K, Oshima T, et al. GJB2 (Connexin 26) mutations and childhood deafness in Thailand. Otol Neurotol. 2001; 22: 858-861.

10. Wang YC, Kung CY, Su MC, Su CC, Hsu HM, Tsai CC, et al. Mutation of Cx26 gene (GJB2) for prelingual deafness in Taiwan. Eur J Hum Genet. 2002; 10: 495-498.

11. bii.a-star.edu.sg.

12. Clark, J. G. Uses and abuses of hearing loss classification. American Speech-Language-Hearing Association (ASHA).1981; 23: 493-500.

13. Calin L., Radu P., Al-Khzouz C., Gheorghe M., Paula G. GJB2 and GJB6 genes mutations in children with nonsyndromic hearing loss. Revista Română de Medicină de Laborator. 2017; 25: 37-46.

14. Yenitse Perea1, Jorge Mato2, Isis Amores2, Raúl Ferreira2. Study of six mutations in the gjb2 gene in Cuban patients with nonsyndromic sensorineural deafness. Biotecnología Aplicada. 2007;24: 241-245.

15. Wangemann P. Comparison of ion transport mechanisms between vestibular dark cells and strial marginal cells. Hear. Res. 1995; 90: 149-157.

16. Martin PE and Evans WH. Incorporation of connexins into plasma membranes and gap junctions. Cardiovasc. Res. 2004; 62: 378-387. 
17. Cifuentes L, Arancibia M, Torrente M, Acuna M, Farfan C, Rios C. Prevalence of the 35 delG mutation in the GJB2 gene in two samples of non-syndromic deaf subjects from Chile.Biol. Res. 2013: 46(3) Santiago.

18. Huang S., Han D., Yuan Y., Wang G., Kang D., Zhang X. et al. “Extremely discrepant mutation spectrum of SLC26A4 between Chinese patients with isolated Mondini deformity and enlarged vestibular aqueductJournal of Translational Medicine. 2011; 9:167.

19. Okamoto Y., Mutai H., Nakano A. Arimoto Y., Sugiuchi T., Masuda S. et al."Subgroups of enlarged vestibular aqueduct in relation to SLC26A4 mutations and hearing loss," Laryngoscope.2014; 124: 134-140.

20. Nishio SY and Usami SI. "Deafness gene variations in a 1120 nonsyndromic hearing loss cohort: molecular epidemiology and deafness mutation spectrum of patients in Japan," The Annals of Otology Rhinology and Laryngology. 2015; 124: 49-60.

21. Fuse Y, Doi K, Hasegawa T, Sugii A, Hibino H, Kubo T. Three novel connexin26 gene mutations in autosomal recessive nonsyndromic deafness. Neuroreport. 2004; 10: 1853-1857.

22. Abe S, Usami S, Shinkawa H, Kelley PM, Kimberling WJ. Prevalent connexin 26 gene (GJB2) mutations in Japanese. J Med Genet. 2000; 37: 41-43.

23. Park HJ, Hahn SH, Chun YM, Park K, Kim HN. Connexin26 mutations associated with nonsyndromic hearing loss. Laryngoscope. 2000; 110: 1535-1538.

24. Cohn ES, Kelley PM. Clinical phenotype and mutations in connexin 26 (DFNB1/GJB2), the most common cause of childhood hearing loss. Am J Med Genet. 1999; 89:130-136.

25. Brobby GW, Muller-Myhsok B, Horstmann RD. Connexin 26 R143W mutation associated with recessive nonsyndromic sensorineural deafness in Africa. N Engl J Med. 1998; 338: 548-550.

\section{Tables}

Table 1: Mutations and parameters for PCR-RFLP.

\begin{tabular}{|c|c|c|c|c|c|}
\hline Primer sequence & Mutation & $\begin{array}{l}\text { PCR } \\
\text { Product } \\
\text { (bp) }\end{array}$ & $\begin{array}{l}\text { Restriction } \\
\text { Enzyme }\end{array}$ & Allele size (bp) & Ref. \\
\hline $\begin{array}{l}\text { F: TGTGTGCATTCGTCTTTTCCAG } \\
\text { R:GGTTGCCTCATCCCTCTCAT }\end{array}$ & c. $235 \mathrm{delC}$ & 722 & Apal & $\begin{array}{l}\text { wild: } 451+277 \\
\text { Hetero:722+ } \\
451+277 \\
\text { Homo: } 722\end{array}$ & $\begin{array}{l}\text { Masyita et al. } \\
2009\end{array}$ \\
\hline $\begin{array}{l}\text { F:TCTTTTCCAGAGCAAACCGC } \\
\text { R:GCTGGTGGAGTGTTTGTTCACA }\end{array}$ & c.35delG & 89 & Bstl & $\begin{array}{l}\text { wild: } 69+20 \\
\text { Hetero: } 89+69 \\
\text { Homo: } 89\end{array}$ & $\begin{array}{l}\text { Freitas et al. } \\
2010\end{array}$ \\
\hline $\begin{array}{l}\text { F: GATTGGGGCACGCTGCA } \\
\text { R: CCCTTGATGAACTTCCTCTTCT }\end{array}$ & c. $167 \mathrm{delT}$ & 322 & Mwol & $\begin{array}{l}\text { wild: } 322 \\
\text { Hetero: } \\
\text { 322+161 } \\
\text { Homo:161 }\end{array}$ & $\begin{array}{l}\text { Shahin et al. } \\
2002\end{array}$ \\
\hline
\end{tabular}


bp: base pair, F: Foreword, R: Reverse, Ref: Reference

Table 2: Clinical characteristics of deaf patients

\begin{tabular}{|c|c|c|c|}
\hline \multicolumn{2}{|l|}{ Parameters } & \multirow{2}{*}{$\begin{array}{l}\text { Simplex proband } \\
\mathrm{n}=75\end{array}$} & \multirow{2}{*}{$\begin{array}{l}\text { Multiplex proband } \\
n=20\end{array}$} \\
\hline$\underline{\text { Sex }}$ & & & \\
\hline Male & 55 & 42 & 13 \\
\hline Female & 40 & 33 & 7 \\
\hline \multicolumn{4}{|c|}{ Age at the test } \\
\hline $6-18$ years & & 40 & 9 \\
\hline $19-40$ years & & 37 & 11 \\
\hline \multicolumn{4}{|c|}{ Severity of hearing loss } \\
\hline Mild & & 0 & 0 \\
\hline Moderate & & 4 & 0 \\
\hline Severe & & 11 & 3 \\
\hline Profound & & 60 & 17 \\
\hline
\end{tabular}

$\mathrm{n}$ : number

Table 3: Frequency of the GJB2 mutations in deaf patients and control groups.

\begin{tabular}{|c|c|c|c|c|c|c|c|c|c|}
\hline \multirow[t]{2}{*}{$\begin{array}{l}\text { GJB2 } \\
\text { mutation }\end{array}$} & \multirow[t]{2}{*}{ Effect } & \multicolumn{3}{|c|}{$\begin{array}{l}\text { Genotype/ } \\
\text { Frequency(\%)of control }\end{array}$} & \multicolumn{3}{|c|}{$\begin{array}{l}\text { Genotype/ } \\
\text { Frequency (\%) of patients }\end{array}$} & \multicolumn{2}{|c|}{ Allele frequency } \\
\hline & & Wild & Hetero & Homo & Wild & Hetero & Homo & $\begin{array}{l}\text { Total } \\
\text { affected }\end{array}$ & \\
\hline c.35delG & frameshift & 110 & - & - & $\begin{array}{l}30 \\
(31.5 \%)\end{array}$ & $\begin{array}{c}4 \\
(4.2 \%)\end{array}$ & $\begin{array}{l}61 \\
(64.2 \%)\end{array}$ & $65(68.4 \%)$ & $0.42 \%$ \\
\hline c.235delC & Frameshift & 110 & - & - & $55(57 \%)$ & $\begin{array}{c}5 \\
(5.3 \%)\end{array}$ & $\begin{array}{l}35 \\
(36.8 \%)\end{array}$ & $40(42.1 \%)$ & $0.68 \%$ \\
\hline c.167delT & Frameshift & \multicolumn{3}{|c|}{ Not detected } & \multicolumn{3}{|c|}{ Not detected } & & - \\
\hline
\end{tabular}

Homo: Homozygous, Hetero: Heterozygous

\section{Figures}




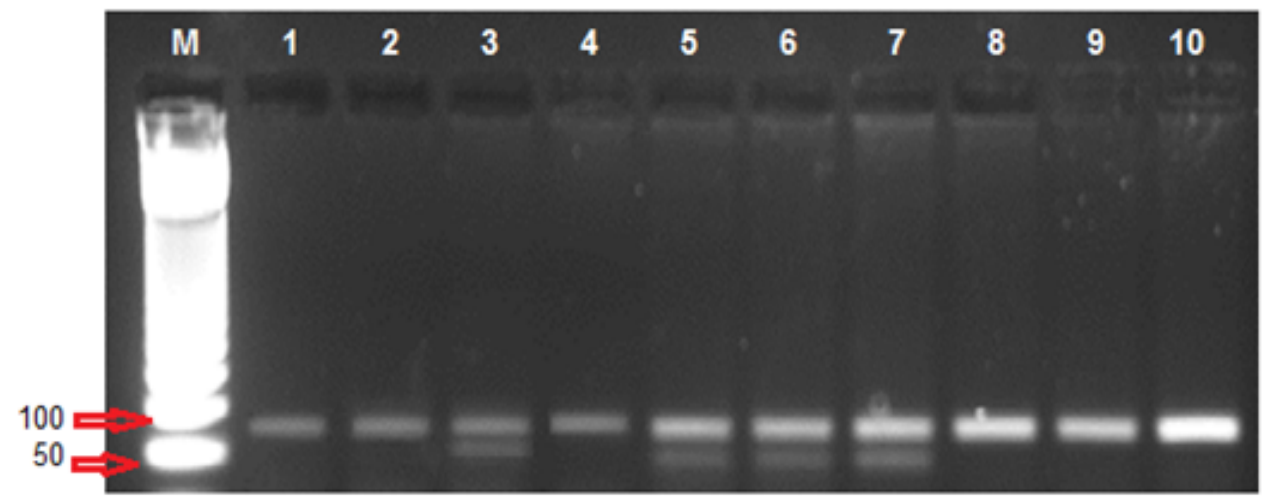

\section{Figure 1}

Restriction analysis by Bstl enzyme for PCR product of c.35delG mutation in GJB2 gene in $2 \%$ agarose gel electrophoresis. Lane M: DNA Ladder. Lane 3, 5, 6, and 7 are heterozygous genotype and Lane 1, 2, 4, 8, 9 and 10 homozygous genotype of mutant alleles.

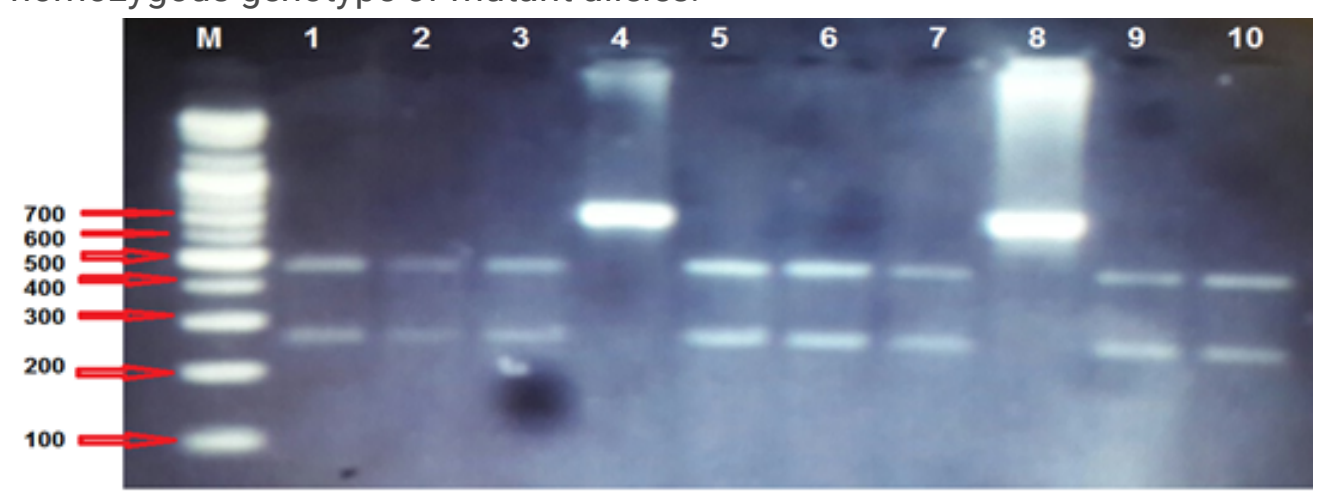

Figure 2

Restriction analysis by Apal enzyme for PCR product of c.235delC mutation in GJB2 gene in $2 \%$ agarose gel electrophoresis. Lane M: DNA Ladder. Lane 1, 2, 3, 5, 6, 7, 9 and 10 are wild genotype and Lane 4, and 8 are homozygous genotype of mutant alleles. 